\title{
Abordagem Computacional sobre Sistemas Baseados em DNA: \\ Da Adsorção em Membranas ao \\ Desenvolvimento de Veículos para Transporte e Entrega de Fármacos
}

Vasco Bonifácio

vasco.bonifacio@tecnico.ulisboa.pt
O design de sistemas para transporte e entrega de fármacos e/ou material genético tem sido um aspeto amplamente escrutinado nos últimos anos e que continua a ser alvo de intensa pesquisa. 0 objetivo deste projeto é desenvolver transportadores que venham a ser clinicamente relevantes para combater doenças elusivas como o cancro, Alzheimer, infeções por bactérias multirresistentes, entre outros, recorrendo a tecnologias moleculares baseadas em ácidos nucleicos (DNA e RNA).

Um dos passos-chave em todo o processo é a interação destes sistemas de polieletrólitos com as barreiras celulares. Neste sentido, o estudo da interação entre polieletrólitos e membranas modelo é um assunto da maior relevância, não só para o desenvolvimento de transportadores eficientes como na interpretação de processos relacionados com a adsorção de proteínas, agregação coloidal e muitos outros.

A simulação computacional é amplamente reconhecida como uma ferramenta poderosa para explorar diferentes aspetos com impacto no desenvolvimento e comportamento destes sistemas, uma vez que abordagens sistemáticas são muitas vezes difíceis de realizar experimentalmente. Este tem sido um dos focos desta equipa de investigação, que recorrendo à simulação coarse-grained e atomística pretende a interpretação e design de sistemas de poliplexos para entrega genética, o desenvolvimento de nanossistemas direcionados ao tratamento da desordem do olho seco e a tumores cerebrais, com particular enfoque no glioblastoma, e em transportadores do tipo DNA-origami para o combate à resistência microbiana.

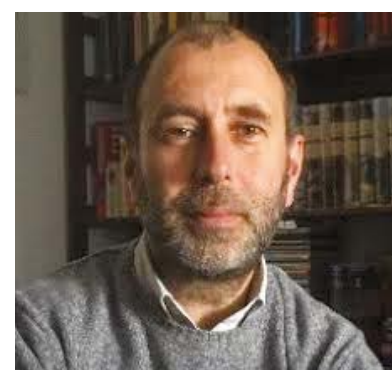

Ficha Técnica do Projeto

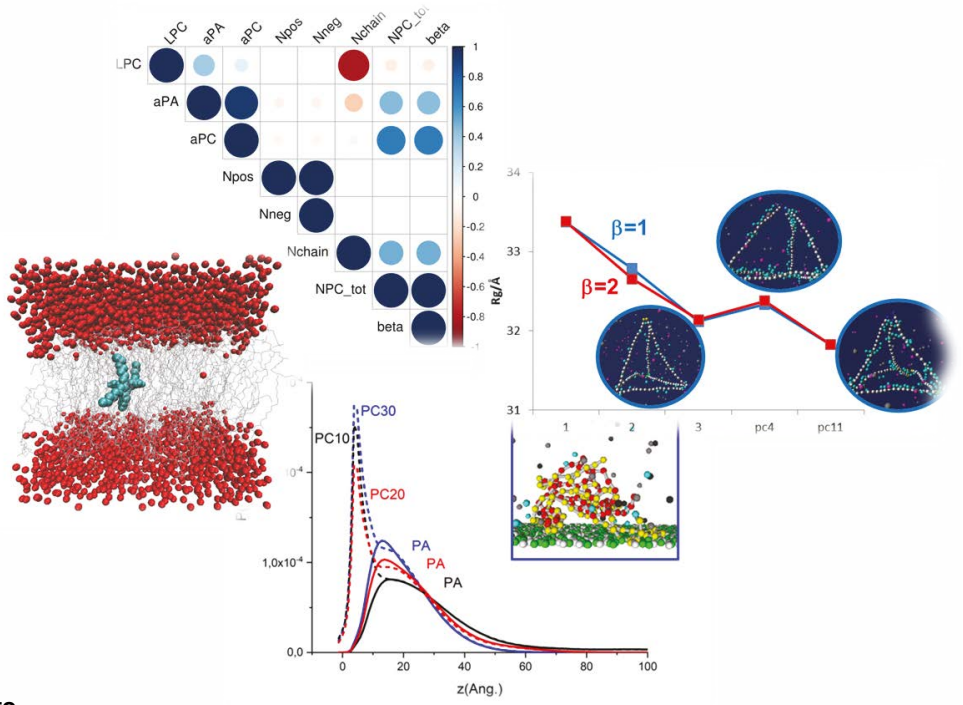

Alberto Canelas Pais

Financiamento: Coimbra Chemistry Centre

(CQC) - UIDB/00313/2020

Equipa: CQC/Universidade de Coimbra - Alberto

Canelas Pais (IR), Sandra Nunes, Tânia Cova, Carla

Vitorino, Maria Mendes, João Basso. 